\title{
MONOCHRONIC VS. POLYCHRONIC: A PROFILE OF ACADEMIC TIME USE AMONG ONLINE DISTANCE EDUCATION STUDENTS
}

\author{
Ana Maria Neves, Lina Morgado, Laboratory of Distance Education and eLearning, \\ Universidade Aberta, Portugal
}

\begin{abstract}
The results presented are part of a doctoral thesis which is being finalized. The research is centred on the online distance learning student experience in higher education, considering the variable time management, its relationship with technologies, and the virtualization of teaching and learning. Exploratory in nature, the research takes the form of a case study using a mixed methodology. One of the main objectives of the study is to contribute to the construction of a theoretical framework on the distance learning student time variable. We present a profile of academic time use by e-students (monochronic or polychronic) and suggest an intermediate profile. The conclusions point out that the profile of academic time use varies according to the degree of the course attended. It was found that undergraduate students show a more polychronic profile than masters and doctoral students.
\end{abstract}

Keywords: distance education students, virtual time, monochronicity, polychronicity

\section{Introduction}

In the traditional university (face-to-face), students are expected to arrive at the classroom at the indicated time and occupy a place in the physical space. There is a predetermined time for teaching and there is generally a tolerance for delays, after which time the student is often prevented from entering. This is the experience of chronological time in Western societies in general. The internet appears as a disruptive technology. Studying online in distance learning settings means living in a new dimension, a new way of inhabiting time and space. The virtual time that results from the digitalization of societies is, at the same time, ephemeral, synchronous and asynchronous, present and future (Duncheon \& Tierney, 2013); it is timeless time, without sequence, undifferentiated and eternal (Castells, 2005). Virtual reality represents the clearest example of disruption, insofar as it allows us to simulate and evaluate the consequences of a particular action in a time that does not yet 
exist, enabling the correction of a predictable reality, tested in the virtual dimension (Lee \& Whitney, 2002).

With regard to online distance education, Ducheon and Tierney, interviewed by Cottier and Lanéelle (2016) identify changes inflicted by virtual time: the limits of space and time have disappeared - learning takes place in a virtual class, where colleagues, teachers and content are potentially available anytime, anywhere; time flexibility has been expanded activities and schedules can be organized according to individual availability and asynchrony favours international classes and classes in which geography and time zones are not limitations; the pace is faster and multitasking is favoured.

\section{Online Academic Time}

In an increasingly fast-paced society, time is a capital resource and a critical success factor, so much so that the skills related to the ability to manage time are already considered key competences of the $21^{\text {st }}$ century (Langa, 2013). Time is a unidirectional and irreversible resource; it cannot be stored for consumption in periods of grace. When time is not well managed, it is lost and cannot be replaced (Langa, 2013). In other words, time is the only resource that runs out doing absolutely nothing.

Despite all the changes stimulated by technologies, most organizations continue to govern themselves with chronological time as their reference point. The distance students are faced with the need to change their view between contexts, depending on whether they are working in a chronological logic of organization or in a logic of virtual organization (Ducheon \& Tierney in Cottier \& Lanéelle, 2016). For example, when the distance students have a certain deadline to meet, they are faced with a chronological logic of organization. However, when faced with an asynchronous activity that will be performed in a team, they may have to organize themselves according to a logic of virtual organization in negotiation with their colleagues.

Difficulties in time management are one of the main regrets of online distance learning students, who report struggling with too many tasks related to their academic life and which they have difficulty reconciling with family support and professional activities (Sánchez-Elvira Panigua \& González Brignardello, 2014). Several studies indicate that distance students show a high deficit of organization and planning of their time, which leads to great anxiety and stress in the period before the assessment tests (Langa, 2013; MacCann, Forgarty, \& Roberts, 2012; Sánchez-Elvira Panigua \& González Brignardello, 2014) and can result in withdrawal and retention. However, time management skills are not independent of personality and, as such, can be trained, a need that is increasingly pressing as teaching virtualization grows (MacCann, Forgarty, \& Roberts, 2012; Nadinloyi 
Neves, A. M., \& Morgado, L.

Monochronic vs. Polychronic: A Profile of Academic Time use Among Online Distance Education Students

et al., 2013). Reinforcing this position, the recent studies by Heo and Han (2018) point to a negative correlation between the high stress levels of online students and the predisposition for autonomous and self-directed learning.

Although the difficulties of time management are identified in all students, women perceive and use time in a different way when compared to men. Often it is women who most indicate that academic responsibilities take them away from family and childcare, often feeling guilty for the time they are no longer able to devote to the family (Stone \& O’Shea, 2013; 2019).

\section{The Use of Time: Monochronic and Polychronic}

The way we perceive time, the way we organize our agendas and set priorities is closely linked to the context in which we were born and educated (Hall, 1959; Hall \& Hall, 1990). Hence, the tendency for Northern Europeans, for example, to have a more monochronic profile than Africans, Arabs or Latin Americans (Fulmer et al., 2014).

Table 1: Characteristics of monochronic and polychronic people

\begin{tabular}{|c|c|}
\hline Monochronic individuals & Polychronic individuals \\
\hline Do one thing at a time & Do many things at once \\
\hline Concentrate on the job & Are highly distractible and subject to interruptions \\
\hline $\begin{array}{l}\text { Take tıme commitments (deadlines, schedules) } \\
\text { seriously }\end{array}$ & $\begin{array}{l}\text { Consider time commitments an objective to be } \\
\text { achieved, if possible }\end{array}$ \\
\hline Are low-context and need intormation & Are high-context and already have information \\
\hline Are committed to the job & Are committed to people and human relationships \\
\hline Adhere religiously to plans & Change plans often and easily \\
\hline $\begin{array}{l}\text { Are concerned about not disturbing others, follow rules } \\
\text { of privacy and consideration }\end{array}$ & $\begin{array}{l}\text { Are more concerned with those who are closely related } \\
\text { (family, friends, close business associates) than with } \\
\text { privacy }\end{array}$ \\
\hline $\begin{array}{l}\text { Show great respect for private property, seldom borrow } \\
\text { or lend }\end{array}$ & Borrow or lend things often and easily \\
\hline Emphasize promptness & Base promptness on the relatıonship \\
\hline Are accustomed to short-term relatıonshıps & Have strong tendency to buld lifetıme relatıonships \\
\hline
\end{tabular}

Although we cannot talk about people who are totally monochronic or totally polychronic, we can talk about profiles of time use that tend to be either monochronic or polychronic (Kaufman, Lane, \& Lindquist, 1991). People who prefer a more monochronic use of time tend to do one task at a time, applying a high level of concentration to the development of the task, have difficulties in managing interruptions, and stick to their plans and schedules scrupulously. On the other hand, people who make use of time in a polychronic way are able to perform several tasks simultaneously and have no difficulty in changing their plans and agendas if necessary. The studies by Kaufman, Lane, and Lindquist (1991) conclude that there is no direct relationship between a more polychronic use of time and the variables age, sex, marital status or income. However, the authors conclude that individuals with higher levels of education and those who work more than 40 hours a week, as well as individuals who are linked to associative activities, tend to make a more polychronic use of time. 
However, in view of the emergence of the virtual time dimension, several authors have been exploring the perception, use and management of time in the online space by online distance learners (Barberà \& Reimann, 2013; Capdeferro, Romero \& Barberà; 2014; Stone $\&$ O'Shea, 2019). Studies indicate that women who attend online courses have a more polychronic profile in terms of the use of time (Stone \& O'Shea, 2019). In the authors' opinion, the greater burden of responsibilities in terms of family management that has to be reconciled with professional and academic responsibilities is decisive in the use of more polychronic time and in multitasking (for example, cooking while studying).

Assuming the definitions of monochrony and polychrony proposed by Bluedorn, Kaufman, and Lane (1992), Hall (1959), Hall and Hall (1990), Kaufman and Lane (1992) and Kaufman, Lane, and Lindquist (1991), and adapting them to the context of the online student, we understand that a student who has the ability to perform various tasks at the same time (for example, typing on the computer while talking on the phone or watching a videoconference), and who values interpersonal relationships and interaction with classmates more, to the detriment of strict compliance with the temporal and timed order of an agenda or commitment, will tend to have a more polychronic profile. On the other hand, students who tend to be monochromic have an extremely organized attitude, plan their commitments in advance and focus on performing one task at a time, tending not to deepen affective relationships with colleagues or the class as a whole. An online distance student with these characteristics tends to prefer a well-structured activity calendar with a defined time allocated to each task (Capdeferro, Romero, \& Barberà; 2014). In this context, there is a high probability that a monochronic student will experience difficulties in adapting to a poorly structured course, of a socio-constructivist nature, and controlled by the student. Likewise, students from a predominantly monochronic social and cultural reality may find it difficult to adapt to eLearning (Martinak, 2012). The flexibility of time, pace and place, which could be considered an asset, if not well managed, can degenerate into procrastination and, ultimately, lead to drop out. Therefore, a good student reception system, the support of peers and the guidance of teachers and tutors are essential (Barberà \& Reimann, 2013; Capdeferro, Romero, \& Barberà, 2014; Carreras \& Valax, 2010; Miertschin, Goodson, \& Stewart, 2015).

\section{Methodological Approach}

Our research has an exploratory nature and takes the form of a case study which uses a mixed methodology of data collection and analysis. The participants in the study are online distance students at the Portuguese distance learning university which pedagogical model is based in asynchrony (Pereira et al., 2008). We resort to document analysis, collection and 
Neves, A. M., \& Morgado, L.

Monochronic vs. Polychronic: A Profile of Academic Time use Among Online Distance Education Students

analysis of online distance students' narratives, surveys and interviews, using intermethod triangulation based on qualitative and quantitative methods.

The survey was designed according to the research objectives and questions, taking into account the categories arising from the literature review, document analysis and analysis of the narratives. Aware of the importance of retaining respondents, we opted for the construction of a survey consisting of closed questions and alternative answers classified on a Likert scale of frequency or agreement. The question order was also designed with the aim of avoiding tiredness and maintaining the respondents' interest, avoiding a mounting effort curve. Ethical issues were assessed and ensured by the Ethics Committee of LE@D (Laboratory of Distance Education and eLearning), the research centre that hosted the present investigation, and the survey was validated by statistical experts.

For the treatment and statistical analysis, we used the SPSS software, version 25 . In the treatment of the data presented in this article, the following procedures and statistical tests were performed: adjustment test, to test the proportion of the sample in relation to the universe; Pearson's Chi-Square test $\left(\chi^{2}\right)$; and Cronbach's alpha coefficient.

\section{Results}

\section{Sample characterization}

The data collected in the survey allows us to present the general profile of the distance students in our sample $(\mathrm{N}=212): 55.7 \%$ of the respondents are women and $44.3 \%$ are men; the most represented age group is $41-50$ (41\%) and the average age is $43.2 .64 .6 \%$ of respondents have dependent children or adults. As for nationality, $87.7 \%$ are Portuguese, followed by Brazilians (6.6\%), Cape Verdeans (2.4\%) and Mozambicans (1.9\%). Other nationalities represent less than $1 \%$ of the sample. Portugal is the country of residence of $78.8 \%$ of respondents. In spite of a high percentage of students who have a professional activity (93.9\%), 66.5\% of respondents attend higher education full time. As for the degree attended, 55.2\% are undergraduate students, 37.7\% Master's students, and $7.1 \% \mathrm{PhD}$ students.

The sample is representative of the public at a mature age who seek to realize in the online university the opportunities they have not had in the past due to professional, financial or family options. The most expressive data of this reality are the $39.3 \%$ of students who enrolled in an online degree via the skills recognition program for people over 23. In addition, $25.6 \%$ of the students entered due to a change of institution or course, and $20.5 \%$ entered after completing 12 years of schooling, often after dozens of years without studying. 
Neves, A. M., \& Morgado, L.

Monochronic vs. Polychronic: A Profile of Academic Time use Among Online Distance Education

Students

\section{Profile of online distance students' time use: monochromic or polychronic?}

In order to verify the profile of academic time use of the students in our sample, we defined 13 items in the survey whose scores would allow us to assess a more monochronic or a more polychronic profile, considering a Likert scale of five levels. Calculating the Cronbach's Alpha coefficient, a good internal consistency was found among the 13 items $($ Cronbach's Alpha = 0.849) $($ Table 2).

Table 2: Cronbach's Alpha coefficient - Time Use Profile: Monochronic or Polychronic

\begin{tabular}{|c|c|c|c|c|}
\hline & $\begin{array}{l}\text { Scale Mean if } \\
\text { item Deleted }\end{array}$ & $\begin{array}{l}\text { Scale } \\
\text { Variance if } \\
\text { item Deleted }\end{array}$ & $\begin{array}{l}\text { Corrected } \\
\text { item total } \\
\text { Correlation }\end{array}$ & $\begin{array}{l}\text { Cronbach's } \\
\text { Alpha if item } \\
\text { Deleted }\end{array}$ \\
\hline 14.4. The online course helps my selt-discipline & 40,50 & $74,7 / 2$ & 367 & , 846 \\
\hline 15.4. I tollow my schedule strictly & 41,33 & 12402 & 496 & 839 \\
\hline 15.6. I tocus on a task at a tıme & 41,13 & 14,292 & 333 & 848 \\
\hline $\begin{array}{l}15 . / \text {. I do the academic tasks according to what is } \\
\text { defined in the curricular units schedule }\end{array}$ & 40,84 & $10,6 / 6$ &, 543 & 835 \\
\hline $\begin{array}{l}\text { 15.8. Whenever I can, I use my daily commute (to and } \\
\text { from work, for example) to study. }\end{array}$ & 42,02 & 69,336 & ,411 & ,84l \\
\hline 16.1. I plan my tasks daily. & 41,42 & 68,310 & ,551 & 835 \\
\hline 16.2. I plan my tasks weekly. & 41,10 & $6 /, 066$ & 633 & 829 \\
\hline 16.3. I plan my tasks monthly. & 41,62 & 69,314 & 488 & 839 \\
\hline 16.4. I differentiate between urgent and important tasks. & 40,45 & $10,5 / 1$ & 604 & 832 \\
\hline $\begin{array}{l}\text { 16.5. I easily refuse leisure activities if they interfere with } \\
\text { my academic plans. }\end{array}$ & 40,88 & 10,080 &, $5 / 9$ & 833 \\
\hline $\begin{array}{l}\text { 16.6. I opt for the dedication to academic work instead of } \\
\text { hobbies, social life or leisure. }\end{array}$ & 40,94 & 69,191 &, 618 & ,831 \\
\hline $\begin{array}{l}16 . / .1 \text { access the curricular units in the online plattorm } \\
\text { daily. }\end{array}$ & 40,68 & 11,521 & 446 &, 842 \\
\hline $\begin{array}{l}\text { 16.8. I plan my oft days to recover what I haven't } \\
\text { managed to do during my working days. }\end{array}$ & 40,58 & $69,9 / 9$ &, 538 & ,836 \\
\hline $\mathrm{N}=212$ & & & \multicolumn{2}{|c|}{ Cronbach's Alpha $=0,849$} \\
\hline
\end{tabular}

Observing and analysing the variation in responses, we found that $25 \%$ of the respondents rated the 13 items at the lowest levels, between 1.46 and 2.92, and these are the students we can consider to have a more pronounced polychronic time use profile. On the other hand, the students who classified the items between the values 3.98 and 4.92 are those with a more monochronic time use profile (Table 3).

Table 3: Extremes and Quartiles Diagram - Time Use Profile: Monochronic or Polychronic

\begin{tabular}{lll|l|l|l|l|l|l} 
& \multicolumn{7}{c}{ Percentiles } \\
& 5 & 10 & 25 & 50 & 75 & 90 & 95 \\
\hline Weighted Average & monochronic/ polychronic & 2,2808 & 2,5385 & 2,9231 & 3,4231 & 3,9808 & $4,30 / 1$ & 4,4615 \\
\hline lukey's Hinges & monochronıc/ polychronic & & & 2,9231 & 3,4231 & 3,9615 & & \\
\hline
\end{tabular}

Considering that there are no people who always behave in a polychronic or in a monochronic way in all situations (Kaufman, Lane, \& Lindquist, 1991), we have surpassed a purely interpretative view of the data and considered an intermediate profile between the monochronic and the polychronic styles. Thus, students with a mixed or intermediate profile are those who rate items between 2.92 and 3.98. At the extremes, we considered the profile to be more pronounced: below 2.92 students with a tendency for a monochronic use of time and above 3.98 students with a tendency for a polychronic use of time. Checking 
Neves, A. M., \& Morgado, L.

Monochronic vs. Polychronic: A Profile of Academic Time use Among Online Distance Education Students

the percentages recorded in each of the styles (monochronic, intermediate and polychronic), we conclude that the highest average is obtained by the intermediate profile recorded in $47.2 \%$ of the sample. The remaining $52.8 \%$ are distributed by the monochronic (27.8\%) and the polychronic (25\%) profiles (Table 4 ).

Table 4: Time use profile: Monochronic or Polychronic

\begin{tabular}{|c|c|c|c|}
\hline & Frequency & Valid \% & Cumulative $\%$ \\
\hline Polychronıc & 59 & 21,8 & 27,8 \\
\hline Intermediate & 100 & $4 / 2$ & 75,0 \\
\hline Monochronıc & 53 & 25,0 & 100,0 \\
\hline & 212 & 100.0 & 100.0 \\
\hline
\end{tabular}

Our research results allowed us to conclude that the time use profile varies according to the degree of the course that students take $\left(\chi_{(4)}^{2}=9.821 ; \mathrm{p}=0.042\right)$. Undergraduate students are those who show a more polychronic time use profile (34.2\%) compared to master students (23.8\%). PhD students are the ones who most show an intermediate profile between monochrony and polychrony (66.7\%), and none of them obtained answers associated with polychronic behaviours regarding the use of academic time (Table 5).

When we cross the time use variables with the gender variable, we find that men $(30.9 \%)$ tend to be more polychronic in terms of academic activities than women (25.4\%); however, the observed differences are not significant $\left(\chi_{(2)}^{2}=2.214 ; \mathrm{p}=0.339\right)$ (Table 6).

Table 5: Course | Time use profile: Monochronic or Polychronic

\begin{tabular}{|c|c|c|c|c|c|c|}
\hline & & & Polychronic & Intermediate & Monochronic & Total \\
\hline \multirow{6}{*}{ 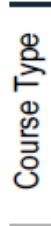 } & Graduation & fr & 40 & 53 & 24 & 111 \\
\hline & & $\%$ Course type & $34,2 \%$ & $45,3 \%$ & $20,5 \%$ & $100,0 \%$ \\
\hline & Master & $\mathrm{fr}$ & 19 & 37 & 24 & 80 \\
\hline & & $\%$ Course type & $23,8 \%$ & $46,3 \%$ & $30,0 \%$ & $100,0 \%$ \\
\hline & $\mathrm{PhD}$ & fr & 0 & 10 & 5 & 15 \\
\hline & & $\%$ Course type & $0,0 \%$ & $66,7 \%$ & $33,3 \%$ & $100,0 \%$ \\
\hline & Total & fr & 59 & 100 & 53 & 212 \\
\hline & & $\%$ Course type & $27,8 \%$ & $47,2 \%$ & $25,0 \%$ & $100,0 \%$ \\
\hline
\end{tabular}

Table 6: Sex/Gender | Time use profile: Monochronic or Polychronic

\begin{tabular}{|c|c|c|c|c|c|c|}
\hline & & & Polychronic & Intermediate & Monochronic & Total \\
\hline \multirow{4}{*}{ 这 } & Female & $f_{r}$ & 30 & 54 & 34 & 118 \\
\hline & & $\%$ & $25,4 \%$ & $45,8 \%$ & $28,8 \%$ & $100,0 \%$ \\
\hline & Male & $\mathrm{fr}$ & 29 & 46 & 19 & 94 \\
\hline & & $\%$ & $30,9 \%$ & $48,9 \%$ & $20,2 \%$ & $100,0 \%$ \\
\hline \multirow[t]{2}{*}{ Total } & & $\mathrm{fr}$ & 59 & 100 & 53 & 212 \\
\hline & & $\%$ & $27,8 \%$ & $47,2 \%$ & $25,0 \%$ & $100,0 \%$ \\
\hline
\end{tabular}

Considering that no significant differences were found in the use of time between men and women, our results are in agreement with the studies by Kaufman, Lane, and Lindquist (1991), who did not find an unequivocal relationship between the sex variables and a more polychronic profile. Still, we highlight the recent studies by Stone and O'Shea (2019), 
Neves, A. M., \& Morgado, L.

Monochronic vs. Polychronic: A Profile of Academic Time use Among Online Distance Education Students

which point to a more polychronic profile among women who study online. According to the authors, this trend arises as a result of a greater burden of domestic chores and family care among women, which requires a greater management effort to reconcile family, work and university.

\section{Summary and Conclusions}

The data indicate that undergraduate distance students tend to place less value on the temporal order of online course activities by committing themselves to several tasks at the same time, as opposed to master and doctoral students who tend to prefer more structured activities, with a time frame allocated to each of them.

The trend towards personalization of learning environments, virtualization and the internationalization of universities, which has been stimulated in the past decade, was unexpectedly and globally precipitated with the advent of Covid-19. The current reality justifies more than ever the development of research with the purpose of creating an evaluation scale of the profile of academic time use exclusively for online distance learning students, as well as understanding which profiles of time use are best adapt to the demands of teaching and learning online.

\section{References}

Barberà, E., \& Reimann, P. (2013). Assessment and Evaluation of Time factors in Online Teaching and Learning. Hershey: Igi Global.

Bluedorn, A., Kaufman, C., \& Lane, P. (1992). How many things do you like to do at once? An introduction to monochronic and polychronic time. Academy of Management Executive, 6(4), 17-26. doi:10.2307/4165091

Capdeferro, N., Romero, M., \& Barberà, E. (2014). Polychronicity: review of the literature and new configuration for the study of his hidden dimension of online learning. Distance Education, 35(3), 294-310. doi:10.1080/01587919.2015.955249

Carreras, O., \& Valax, M. F. (2010). Temporal structure and flexibility in distance work and learning. eLC Research Paper series, 1, 61-70. Barcelona: eLearn Center. UOC. hal$01628387 f$

Castells, M. (2005). A Sociedade em Rede. A Era da Informação: Economia, Sociedade e Cultura (Vol. 1, $2^{\text {nd }}$ ed.). Lisboa: Fundação Calouste Gulbenkian

Cottier, P., \& Lanéelle, X. (2016). Introduction au numéro thématique «Enseignement et formation en regime numérique: nouveaux rythmes, Nouvelles temporalités?» DMS/DMK Distances et mediations des savoirs. Distance and Mediation of Knowledge [Online], 16. Retrieved from https://journals.openedition.org/dms/1638 
Ducheon, J. C., \& Tierney, W. G. (2013). Changing Conceptions of Time: Implications for Educational Research and Practice. Review of Educational Research, 83, 236-272. doi:10.3102/0034654313478492

Fulmer, C. A., Crosby, B., \& Gelfand, M. J. (2014). Cross-cultural perspectives on time. Time and Work. In A. J. Shipp \& Y. Fried (Eds.), Time and Work, Volume 2: How time impacts groups, organizations and methodological choices (pp. 53-75). London: Psychology Press. doi:10.4324/9781315798370

Hall, E. (1959). The Silent Language. New York: Doubleday \& Company, Inc.

Hall, E., \& Hall, M. (1990). Understanding Cultural Differences. German, French and Americans. London: Intercultural Press.

Heo, J., \& Han, S. (2018). Effects of motivation, academic stress and age in predicting selfdirected learning readiness (SDLR): Focused on online college students. Education and Information Technologies, 23(1), 61-71. doi:10.1007/s10639-017-9585-2

Kaufman, C. F., Lane, P. M., \& Lindquist, J. D. (1991). Exploring more than 24 hours a day: A preliminary investigation of polychronic time use. Journal of Consumer Research, 18(3), 392-401. doi:10.1086/209268

Langa, C. (2013). Management of time resources for learning through individual study in higher education. Procedia - Social and Behavioral Sciences, 76, 13-18. doi:10.1016/j.sbspro.2013.04.065

Lee, H., \& Whitley, E. A. (2002). Time and Information Technology: Temporal Impacts on Individuals, Organizations and Society. The Information Society, 18(4), 235-240. doi:10.1080/01972240290075084

MacCann, C., Forgarty, G., \& Roberts, R. (2012). Strategies for success in education: Time management is more important for part-time than full-time community college students. Learning and Individual Differences, 22(5), 618-623. doi:10.1016/j.lindif.2011.09.015

Martinak, M. L. (2012). Virtually Stress Free: Keeping Online Graduate Management Students Healthy From Afar. The Journal of Continuing Higher Education, 60(3), 165174. doi:10.1080/07377363.2013.722419

Miertschin, S., Goodson, C., \& Stewart, B. (2016). Time Management Skills and Student Performance in Online Courses. The ASEE Computers in Education (COeD) Journal, 7(2), 37. Retrieved from http://aseecoed.org/index.php/coed/article/view/236 
Nadinloyi, K., Hajloo, N., Garamaleki, N., \& Sadeghi, H. (2013). The Study Efficacy of Time Management Training on Increase Academic Time Management of Students. Procedia - Social and Behavioral Sciences, 84, 134-138. doi:10.1016/j.sbspro.2013.06.523

Pereira, A., Quintas-Mendes, A., Morgado, L., Amante, L., \& Bidarra, J. (2008). Universidade Aberta's Pedagogical Model for Distance Education, A University for the Future. Lisbon: Universidade Aberta. Retrived from http://hdl.handle.net/10400.2/2388 (translation of the 1st Portuguese version 2007)

Romero, M., Barberà, E. (2014). Computer-Based Creative Collaboration in Online Learning. Proceedings of the Conference on New Horizons in Web-Based Learning, 330336. Berlin, Heidelberg: Springer. Retrieved from https://link.springer.com/chapter/10.1007/978-3-662-43454-3_34

Sánchez-Elvira Panigua, A., \& González Brignardello, M. (2014). Las Comunidades Virtuales de Acogida de la UNED: un espacio de investigación para el desarrollo de medidas de apoyo al estudiante nuevo. In A. Sánchez-Elvira Panigua \& S. Lancho (Eds.), Innovación en entornos de blended-learning (Vol. II, pp. 189-218). Madrid: UNED. Retrieved from http://espacio.uned.es/fez/eserv/bibliuned:501062/LibroIV_Redes.pdf

Stone, C., \& O’Shea, S. E. (2013). Time, money, leisure and guilt - the gendered challenges of higher education for mature-age students. Australian Journal for Adult Learning, 53(1), 95-116. Retrieved from https://ro.uow.edu.au/cgi/viewcontent.cgi?referer=https://scholar.google.pt/\&httpsre $\operatorname{dir}=1 \&$ article $=1193 \&$ context $=$ ss papers

Stone, C., \& O’Shea, S. E. (2019). My children... think it's cool that Mum is a uni student: Women with caring responsibilities studying online. Australasian Journal of Educational Technology, 35(6), 97-110. doi:10.14742/ajet.5504

\section{Acknowledgments}

The results presented are part of a $\mathrm{PhD}$ research integrated in the Laboratory of Distance Education and eLearning (LE@D), an R\&D unit at Universidade Aberta, Portugal. The $\mathrm{PhD}$ thesis is financed by a Research Grant with the reference SFRH / BD / 137859/2018, within the scope of the POCH - Human Capital Operational Program, co-funded by the European Social Fund and by national funds from MCTES through FCT - Foundation for Science and Technology. 